ISSN : 2550-0198

\title{
PEMBUATAN LUBANG RESAPAN BIOPORI SEBAGAI ALTERNATIF PENANGGULANGAN BANJIR DI KELURAHAN MAHARATU KECAMATAN MARPOYAN DAMAI PEKANBARU
}

\author{
Elsie*, Israwati Harahap, Nofripa Herlina, Yeeri Badrun, Novia Gesriantuti \\ Program Studi Biologi, Fakultas MIPA dan Kesehatan \\ Universitas Muhammadiyah Riau \\ *Email: elsie@umri.ac.id
}

\begin{abstract}
Banjir merupakan masalah yang hampir setiap tahun melanda wilayah perkotaan maupun pedesaan. Banjir disebabkan karena tidak lancarnya saluran pembuangan air (di selokan atau badan air) yang menyebabkan terjadinya luapan air, kurangnya kesadaran masyarakat untuk tidak membuang sampah ke aliran air, dan berkurangnya lahan terbuka yang berguna untuk resapan air. Penyebab banjir di wilayah perkotaan lebih banyak disebabkan oleh tidak lancarnya aliran air (di selokan) akibat sampah yang dibuang ke aliran air dan berkurangnya daerah resapan air di pekarangan rumah. Tujuan dari kegiatan pengabdian masysrakat ini adalah untuk meningkatkan pengetahuan dan keterampilan masyarakat di Kelurahan Maharatu, Kecamatan Marpoyan Damai dalam pembuatan lubang biopori sebagai upaya untuk penanggulangan dan pencegahan banjir di sekitar pemukiman masyarakat tersebut yang nantinya dapat diaplikasikan oleh masyarakat di lingkungan sekitar rumah.
\end{abstract}

Kata kunci: Lubang Resapan Biopori, Banjir, Kompos

\section{PENDAHULUAN}

Pada saat ini, banyak sekali wilayah Indonesia yang tidak terbebas dari banjir. Baik di perkotaan maupun di pedesaan. Banjir yang terjadi bukan hanya berdampak pada wilayah dimana terjadinya banjir tersebut, tetapi juga pada wilayah-wilayah sekitar banjir. Dampak yang ditimbulkan sangat beragam, mencakup beberapa aspek kegiatan manusia seperti kesehatan, social, pendidikan hingga perekonomian. Penyebab banjir antara lain saluran-saluran pembuangan air serta sungai yang tidak lancar alirannya sehingga mengakibatkan luapan air sungai, kurangnya kesadaran manusia untuk tidak membuang sampah ke aliran air, dan berkurangnya lahan terbuka yang berguna untuk resapan air. Penyebab banjir di perkotaan lebih banyak disebabkan oleh tidak lancarnya aliran air akibat sampah yang dibuang ke badan air dan lahan resapan air yang semakin berkurang. Setiap kita dapat ikut berperan untuk mencegah terjadinya banjir dan dapat dimulai dari sekitar tempat tinggal kita. Penanggulangan banjir untuk daerah yang sudah mulai berkurang daerah resapan air dapat diatasi dengan pembuatan lubang resapan biopori (LRB) (Sutandi et. al, 2013).

Selain mencegah banjir, LRB juga dapat membantu mengurangi kekeringan dan membantu 
ISSN : 2550-0198

mengurangi beban sampah kota. Menurut (Brata \& Nelistya, 2008), teknologi LRB merupakan produk yang sederhana, murah dan tidak memerlukan lahan yang luas, serta cepat dan mudah dalam pembuatannya. LRB sangat tepat diterapkan pada lokasi yang memiliki kepadatan bangunan dan pemukiman penduduk. Menurut Peraturan Menteri Lingkunan Hidup Nomor 12 Tahun 2009 tentang Pemanfaatan Air Hujan, LRB adalah lubang yang dibuat secara tegak lurus ke dalam tanah, dengan diameter $10-25 \mathrm{~cm}$ dan kedalaman sekitar $100 \mathrm{~cm}$ atau tidak melebihi kedalaman muka air tanah. LRB sangat tepat diterapkan pada lingkungan perkotaan yang memiliki kondisi permukiman dengan kepadatan penduduk yang tinggi karena lahan yang dibutuhkan untuk LRB relatif kecil (Mulyaningsih et al. 2014).

LRB merupakan lubang kecil di dalam tanah yang terbentuk karena adanya aktivitas organism tanah seperti cacing, pergerakan akar di dalam tanah, rayap dan hewan-hewan lainnya. Lubang terisi oleh udara hingga memasuki aliran air. Air hujan tidak secara langsung masuk ke dalam selokan tetapi merembes ke dalam tanah melalui lubang tersebut. LRB dapat dibuat di halaman depan, belakang atau kebun dari rumah. LRB dengan diameter $20 \mathrm{~cm}$ dan kedalaman $15 \mathrm{~cm}$ dengan jarak $2 \mathrm{~m}$ terbukti sangat efektif dalam mencegah terjadinya mengalirnya air permukaan, erosi dan kehilangan nutrient di lahan pertanian (Permatasari, 2015).

Kelurahan Maharatu merupakan salah satu kelurahan yang berada di dalam Kecamatan Marpoyan Damai, Kota Pekanbaru dengan luas wilayah
$11,26 \mathrm{~km}^{2}$ dengan jumlah Rukun Warga (RW) Tingginya penggunaan lahan untuk bangunan/pekarangan perumahan menyebabkan berkurangnya daerah resapan air. Kondisi ini makin diperburuk karena banyak halaman rumah warga yang disemenisasi sehingga apabila terjadi hujan air yang meresap ke dalam tanah makin berkurang. Sampai sejauh ini, sebagian besar masyarakat di Kelurahan Maharatu, khususnya di RT 03/RW 07 belum menerapkan teknologi lubang resapan biopori sebagai alternatif penanggulangan banjir dan mengurangi beban sampah organik rumah tangga.

Kegiatan pengabdian kepada masyarakat ini bertujuan untuk meningkatkan pengetahuan dan keterampilan masyarakat di Kelurahan Maharatu, Kecamatan Marpoyan Damai dalam pembuatan lubang biopori sebagai upaya untuk penanggulangan dan pencegahan banjir di sekitar pemukiman masyarakat tersebut.

\section{METODE PENGABDIAN}

Pelaksanaan kegiatan pengabdian ini dalam bentuk penyuluhan dan pelatihan pembuatan Lubang Resapan Biopori (LRB).

\section{Penyuluhan tentang Lubang Resapan Biopori}

Sebelum dilakukan pembuatan lubang biopori, dilakukan penyuluhan tentang apa itu lubang resapan biopori, manfaat serta bagaimana cara pembuatannya. Penyuluhan dilakukan dilakukan di salah satu rumah warga dimana lokasi kegiatan ini berlangsung. Tujuan dilakukannya penyuluhan ini adalah untuk member informasi awal tentang 
lubang resapan biopori dan manfaatnya dalam menanggulangi dan mencegah banjir.

\section{Pembuatan Lubang Resapan Biopori}

Setelah penyuluhan tentang lubang resapan biopori dilakukan, langkah selanjutnya adalah mempersiapkan peralatan dan bahan yang dibutuhkan. Peralatan yang diperlukan hanya linggis dan bor khusus untuk pembuatan lubang biopori. Setelah lokasi pembuatan lubang resapan biopori dipilih langkah selanjutnya adalah melakukan pengeboran atau pelubangan. Langkah-langkah yang dilakukan adalah sebagai berikut:

a. Lubang silindris dengan diameter $10 \mathrm{~cm}$ dan kedalaman $100 \mathrm{~cm}$ dibuat secara vertikal ke dalam tanah menggunakan bor. Jika akan dibuat lebih dari 1 lubang resapan biopori maka beri jarak $50-100 \mathrm{~cm}$ antar lubang.

b. Sepanjang $30-40 \mathrm{~cm}$ dari permukaan tanah dipasang pipa paralon dengan diameter $10 \mathrm{~cm}$. Pemasangan pipa tersebut dilakukan bertujuan agar tanah yang di permukaan atas tidak longsor ke dalam LRB yang sudah dibuat. Mulut lubang kemudian ditutup dengan tutup pipa juga.

c. Lubang resapan biopori yang sudah terbentuk, dapat diisi dengan sampah-sampah organik (dapat berupa daun-daun kering, potongan rumput, ranting pohon yang telah jatuh dan limbah organik rumah tangga lainnya) di sekitar pekarangan rumah .

d. Kompos yang sudah terbentuk dapat dikumpulkan untuk dimanfaatkan kembali dalam menyuburkan tanaman yang ada di sekitar pekarangan rumah masyarakat.

\section{HASIL DAN PEMBAHASAN}

Kegiatan penyuluhan dan pembuatan lubang resapan biopori dilaksanakan di Kelurahan Maharatu, Kecamatan Marpoyan Damai, Pekanbaru, pada hari Sabtu tanggal 12 Agustus 2017. Kegiatan dihadiri oleh 18 orang ibu-ibu rumah tangga yang tinggal di RT 03/RW 07. Kegiatan diawali dengan penyuluhan untuk menyampaikan materi tentang Lubang Resapan Biopori. Setelah penyampaian materi, dilanjutkan diskusi singkat dan diakhiri dengan praktik langsung pembuatam lubang resapan biopori.

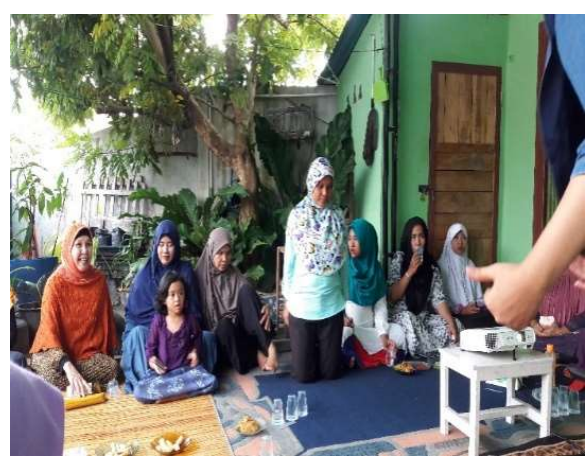

Gambar 1. Suasana diskusi saat penyampaian materi tentang Lubang Resapan Biopori

Pada saat diskusi berlangsung, ada sekitar 6 pertanyaan yang disampaikan peserta seputar lubang resapan biopori. Peserta ada yang bertanya tentang pembuatan lubang resapan biopori dan bagaimana cara pemasangan pipa paralon untuk menghindari terjadinya longsor di dalam lubang tersebut. Peserta juga bertanya tentang kegunaan lubang 
ISSN : 2550-0198

resapan biopori selain untuk mencegah banjir juga dapat dmanfaatkan untuk menghasilkan pupuk kompos. Kompos dibuat hanya dengan cara mengumpulkan daun-daun, rumput-rumput kering dan ranting kecil, sehingga tidak perlu lagi membakar sampah-sampah tersebut. Setelah beberapa minggu, kompos yang dihasilkan dapat diambil untuk dimanfaatkan oleh ibuibu tersebut dalam merawat dan memelihara tanaman di sekitar pekarangan rumah.

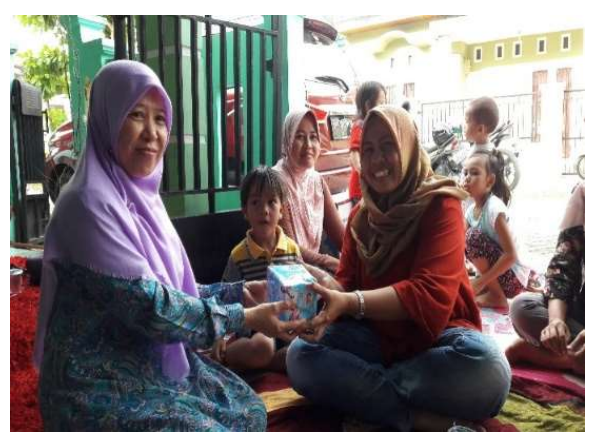

Gambar 2. Pemberian hadiah bagi peserta yang terlibat aktif dalam diskusi (tanya jawab)

Melihat tujuan kegiatan pengabdian ini untuk untuk meningkatkan pengetahuan dan keterampilan masyarakat dalam pembuatan lubang biopori sebagai upaya untuk penanggulangan dan pencegahan banjir di sekitar pemukiman masyarakat tersebut, dapat dikatakan tujuan kegiatan ini tercapai. Hal ini terlihat dari antusias peserta saat mengikuti penyuluhan dan pembuatan lubang resapan biopori. Besar harapan dari pihak pelaksana pengabdian, masyarakat dapat mengaplikasikan pembuatan LRB untuk penanggulangan banjir dann menghasilkan kompos. Hal ini diperkuat dari wawancara langsung dengan masyarakat tersebut yang menyebutkan beberapa rumah terkena banjir karena halaman rumah sebagian besar sudah ditutup dengan semen.

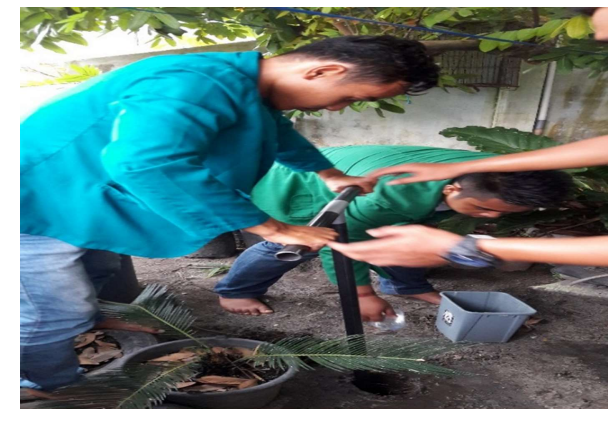

Gambar 3. Praktik pembuatan lubang resapan biopori

\section{SIMPULAN}

1. Kegiatan penyuluhan dan pembuatan lubang resapan biopori di Kelurahan Maharatu, Kecamatan Marpoyan Damai, Pekanbaru telah berhasil dilakukan seperti yang telah direncanakan sebelumnya.

2. Pemahaman peserta kegiatan pengabdian manfaat dan pembuatan lubang resapan biopori menjadi lebih baik.

3. Peserta kegiatan pengabdian akan melanjutkan pembuatan lubang resapan biopori untuk mencegah banjir dan menghasilkan kompos di lingkungan rumah mereka.

\section{UCAPAN TERIMA KASIH}

Terima kasih kami sampaikan kepada Universitas Muhammadiyah Riau (UMRI) sebagai pemberi dana kegiatan pengabdian ini, Ketua RT 03/RW 07 dan masyarakat di Kelurahan Maharatu, Kecamatan Marpoyan Damai, Pekanbaru, dan 
mahasiswa serta dosen Prodi Biologi atas bantuan dan kerjasamanya hingga terselenggaranya kegiatan pengabdian ini.

\section{DAFTAR PUSTAKA}

[1] BPS Kota Pekanbaru. 2014. Kecamatan Marpoyan Damai dalam Angka 2014.

[2] Brata, R. \& A. Nelistya. 2008. Lubang Resapan Biopori. Jakarta. Penebar Swadaya

[3] Mulyaningsih, T., P. Purwanto, \& D. P. Sasongko. 2014. Status Keberlanjutan Ekologi pada Pengelolaan Lubang Resapan Biopori di Kelurahan Langkapura, Kecamatan Langkapura, Kota Bandar Lampung. Jurnal Ilmu Tanah dan Agroklimatologi 11 (2).

[4] Permatasari, L. 2015. Bioinfiltration Hole: "One Day For Biopore" as an Alternative Prevent Flood. International Journal of Advances in Science Engineering and Technology: Vol 3 (2).

[5] Sutandi, M.C., G. Husada, K. Tjandrapuspa, D. Rahmat, dan T. Sosanto. 2013. Penggunaan Lubang Resapan Biopori untuk Minimalisasi Dampak Bahaya Banjir pada Kecamatan Sukajadi, Kelurahan sukawarna, RW 004, Bandung. Konferensi Nasional Teknik Sipil 7, Universitas Sebelas Maret. 